\title{
Long-term brine impacted fly ash, Part II: Mobility of major species in the ash residues
}

\author{
O. O. Fatoba $\cdot$ L. F. Petrik $\cdot$ R. O. Akinyeye • \\ W. M. Gitari • E. I. Iwuoha
}

Received: 14 May 2012/Revised: 7 May 2013/Accepted: 26 May 2013/Published online: 28 June 2013

(C) Islamic Azad University (IAU) 2013

\begin{abstract}
The leaching of major species from fly ash is a function of the $\mathrm{pH}$ of the solution in contact with the fly ash. The aim of this study was to determine the effect of the $\mathrm{pH}$ of the leachant on the leaching of species from the ash residues recovered after the long-term fly ash-brine interactions. Acid neutralization capacity (ANC) tests using solutions of different $\mathrm{pH}$ values ranging from the initial $\mathrm{pH}$ of the ash residues (11-12) to $\mathrm{pH} 4$ were employed in the leaching experiments. The ANC tests revealed that the release of major species from the ash residues depended on the $\mathrm{pH}$ of the leachants except for $\mathrm{Na}$ and $\mathrm{Cl}$, where the significant concentrations leached were independent of the solution $\mathrm{pH}$. The concentrations of $\mathrm{Al}$ and $\mathrm{Si}$ in the ANC leachates were very high at $\mathrm{pH}$ below 6 while $\mathrm{Ca}, \mathrm{K}, \mathrm{Sr}$, $\mathrm{Mg}$ and $\mathrm{B}$ were immediately mobilized from the brine impacted fly ash when in contact with de-ionized water, and leaching increased as the $\mathrm{pH}$ decreased. The concentration of $\mathrm{SO}_{4}$ leached from the brine impacted ash residues at high $\mathrm{pH}$ was high, and the leaching increased with decrease in the $\mathrm{pH}$ of the leachant. This study shows that most of the major elements captured in the ash residues could be mobilized when in contact with aqueous solutions
\end{abstract}

O. O. Fatoba $(\bowtie) \cdot$ L. F. Petrik · R. O. Akinyeye

Environmental and Nano Sciences Research Group,

Chemistry Department, University of the Western Cape,

Private Bag X17, Bellville 7535, South Africa

e-mail: ofatoba@uwc.ac.za

W. M. Gitari

Department of Ecology and Resources Management, School of Environmental Sciences, University of Venda, Private Bag X5050, Thohoyandou 0950, Limpopo, South Africa

E. I. Iwuoha

Sensor Lab, Chemistry Department, University of the Western Cape, Private Bag X17, Bellville 7535, South Africa of various $\mathrm{pH}$. This reveals that the co-disposal of fly ash and brine may not be the best practice as the major elements captured in the ash residues could leach over time.

Keywords Acid neutralization capacity (ANC) - Brine · Fly ash $\cdot$ Major species $\cdot$ Mobility $\cdot$ Co-disposal

\section{Introduction}

The combustion of coal to generate electricity is ongoing in most countries of the world, but the waste materials generated during the combustion process are a major concern because of their environmental implications. Fly ash is one of the major solid wastes by-products generated during the combustion of coal. South African power utilities generate significant quantities (about $40 \mathrm{Mt}$ ) of fly ash annually of which the power stations operated by ESKOM South Africa generate $25 \mathrm{Mt}$ of the fly ash annually (ESKOM Report 2013). Due to the large quantities of ash generated and the need for its careful disposal because of its chemical composition, many countries including South Africa have devised different methods of ash disposal. According to Sushil and Batra (2006), there are two different methods of fly ash disposal operated by power stations in India. These are wet and dry disposal techniques. South African power utilities employ dry and dense slurry disposal techniques. For instance, at Secunda power station, the ash is added from the hoppers to a stirring tank with continuous addition of brine (hyper saline wastewater generated from water treatment plants) to make a slurry with controlled density. This is then pumped continuously via pipes to the ash dam where the ash particles immediately settle out and the ashwater is either drained away via a penstock to the clear ash effluent dam, or percolates through the ash dam and is 
collected in a toe drain. The case of Tutuka power station is different in that the fly ash recovered from the ash hoppers is moistened with low amounts (about $16 \%$ ) of brine before being taken to the ash dumps via conveyor belt for disposal. At the ash dump, the ash is irrigated with brine for dust suppression. The safe disposal of fly ash has been a major issue because of the possible leaching of species from the waste material to the receiving environment including surface and groundwater. The leaching of species from fly ash or municipal solid waste incineration (MSWI) ash depends on several factors which include physical and chemical composition of the fly ash (Dijkstra et al. 2006). The leaching of species from fly ash also depends on the pH of the leachant (Gitari et al. 2009; Van der Sloot and Dijkstra 2004). Any aqueous flow that percolates or comes in contact with the fly ash dissolves or precipitates the species (Dijkstra et al. 2006) depending on its $\mathrm{pH}$. The release of species from fly ash systems is primarily controlled by the solubility of various mineral phases at different $\mathrm{pH}$ levels (van Herreweghe et al. 2002). Acid neutralization capacity (ANC) tests have been carried out severally to determine the mobility of species at different pH from MSWI ash (Astrup et al. 2006) and fly ash (Vitkova et al. 2009), but much have not been reported on the effect of leachant of different $\mathrm{pH}$ on brine impacted fly ash. This was due to lack of adequate attention at understanding the interaction chemistry of fly ash and brine during co-disposal. This necessitated the long-term fly ashbrine interaction study which was designed to understand the chemistry of the ash when co-disposed with brine. The long-term fly ash-brine interaction study started in March 2009 in South Africa (details in Part I), after which the ash residues recovered from the interaction tests were stored and later used in this study. However, the current study focuses on the leaching of major species from the ash residues recovered from fly ash-brine interaction tests at different $\mathrm{pH}$. This was designed to better understand the effect of the long-term interaction of fly ash and brine on the release of the major species from the ash residues when in contact with solutions of different $\mathrm{pH}$. In order to achieve the aim of this study, the ANC leaching test was carried out on the ash residues recovered after the fly ashbrine interaction tests (experimental details in section "Materials and methods"). The ANC test is expected to give an insight into the leaching trends for various component species in the ash residues when in contact with ultrapure water or solutions of lower $\mathrm{pH}$. In the real ash disposal scenario, the extreme high $\mathrm{pH}$ (12) condition of the ash systems is possible when freshly dumped fly ash is in contact with normal rain water while the lower $\mathrm{pH}$ condition is possible as a result of continuous dissolution and leaching of alkalinity-contributing species over time. Apart from this, very low $\mathrm{pH}$ (4) condition of the ash systems can be attained as a result of acid rain caused by the emission of gases such as $\mathrm{SO}_{2}$ during coal combustion process in the power station. The elements such as $\mathrm{Al}, \mathrm{Si}$ and $\mathrm{Ca}$ that were observed to leach out of the fly ash into the brine solution during the long-term fly ash-brine interaction experiments (reported in Part I) were also considered in this study to determine the possibility of their continuous mobility when in contact with water or solutions of lower $\mathrm{pH}$.

\section{Materials and methods}

Long-term brine impacted fly ash residues

The long-term fly ash-brine interaction experiments were carried out as described in Part I of this study. The ash residues recovered after each experiment was oven-dried at $50{ }^{\circ} \mathrm{C}$. The oven-dried residues were crushed, milled, homogenized and stored in tightly closed plastic containers at room temperature for the ANC tests. The ash residues were labeled as follows: SAC, SBC, SCC and SDC are the residues of SFA fly ash-brine interaction experiments at 1 week, 1 month, 6 months and 12 months, respectively, and TAC, TBC, TCC and TDC are the residues of TFA fly ash-brine interaction experiments at 1 week, 1 month, 6 months and 12 months, respectively.

Chemical analysis of brine impacted fly ash residues

The chemical analysis of the brine impacted fly ash samples was performed using X-ray fluorescence (XRF) with a Philips 1404 Wavelength Dispersive Spectrometer fitted with an Rh tube. The samples were oven-dried at $105{ }^{\circ} \mathrm{C}$ for $12 \mathrm{~h}$ to remove the water content.

\section{Acid neutralization capacity experiment (ANC)}

The ANC test was carried out on the ash residues recovered after the long-term fly ash-brine interaction tests based on the methodology of the European standard prEN 14429. The ANC experiment was carried out in South Africa in June 2010. The method is divided into two stages which are; the preliminary test to determine the acid consumption of the fly ash-brine interactions residues; followed by the determination of ANC of the fly ash-brine residues.

\section{Stage 1: determination of acid consumption}

According to prEN 14429 (CEN 2003), the preliminary determination of the acid consumption of the solid residues was done to determine the volume and the concentration of acid needed to attain eight (8) different final $\mathrm{pH}$ values 
between the natural $\mathrm{pH}$ of the ash residues and $\mathrm{pH} 4$. Approximately $15 \mathrm{~g}$ of each of the ash residue samples was weighed into a rinsed bottle. One hundred and thirty-five milliliters of de-mineralized water was added to each ash residue in a bottle, which was equivalent to a liquid/solid ratio (L/S) 9:1 (this was done in order to attain a liquid/solid ratio ranging from 10:1 to 11:1 after the addition of the acid solution). The mixture was agitated for $1 \mathrm{~h}$. The natural $\mathrm{pH}$ value of the eluate was determined after leaving the mixture to settle down for $10 \mathrm{~min}$. In order to determine the amount of acid required to attain different predetermined $\mathrm{pH}$ by the ash residues, different amounts of $2 \mathrm{M} \mathrm{HNO}_{3}$ solution were added to each of the different bottles containing the ash residues as specified. The $\mathrm{pH}$ value was determined for each sample after $30 \mathrm{~min}$ of agitation. This process continued for $24 \mathrm{~h}$ until the different predetermined $\mathrm{pH}$ values ranging from the natural $\mathrm{pH}$ to $\mathrm{pH} 4$ were obtained. The amount of the $2 \mathrm{M} \mathrm{HNO}_{3}$ required to attain each of the set $\mathrm{pH}$ values was recorded and used for the main ANC test.

\section{Stage 2: main ANC experiment}

The main ANC experiment was carried out using the results of the preliminary acid consumption test. Different leachants were prepared by adding different amounts of $2 \mathrm{M} \mathrm{HNO}_{3}$ to each of the bottles containing de-mineralized water (based on the amounts of $2 \mathrm{M} \mathrm{HNO}_{3}$ required to attain the predetermined $\mathrm{pH}$ as calculated from the preliminary test) and made up to $150 \mathrm{~mL}$. Each of these leachant solutions containing different amounts of $\mathrm{HNO}_{3}$ was divided into three equal parts. Fifteen grams of each of the ash residues was placed in 250-mL bottles, and the divided leachants were added to each bottle at three different times (according to CEN 2003). The bottles were closed, and the suspensions agitated each time a portion of the leachant was added, and the $\mathrm{pH}$ value was also measured and recorded after each leachant addition. After the addition of the last portion of the leachants to each of the ash residue solutions, the suspensions were agitated until $t=t_{0}+48 \mathrm{~h}$. The $\mathrm{pH}$, EC and TDS were measured before the ash residue was separated from the leachates after $48 \mathrm{~h}$ by filtration using a membrane filter of $0.45 \mu \mathrm{m}$. The leachates were preserved in a refrigerator at $4{ }^{\circ} \mathrm{C}$ before the elemental analysis was done using IC and ICP-MS for anions and cations, respectively.

\section{Results and discussion}

Chemical composition of the ash residues

The XRF analysis of the residues recovered after the longterm fly ash-brine interaction tests showed that the concentrations of most of the elements in the residues were higher than what was observed in the fresh fly ashes (SFA and TFA) while the concentrations of some elements in the residues reduced after the long-term interaction tests (Tables 1 and 2). Elements such as $\mathrm{Na}, \mathrm{Cl}$ and $\mathrm{SO}_{4}$ were significantly increased in the SAC, SBC, SCC and SDC indicating their removal from the brine solution during the interaction tests. The behavior of $\mathrm{Na}$ and $\mathrm{Cl}$ was similar in the TAC, TBC, TCC and TDC except for $\mathrm{SO}_{4}$ which concentration was lower than what was observed in the TFA at the beginning of the tests. The observed significant increase in the concentration of these species in the residues could be as a result of formation of secondary mineral phases associated with these species and/or as a result of the elements trapped in the pore water which remained in the residues after drying. The slight reduction in the concentration of $\mathrm{Al}, \mathrm{Ca}$ and $\mathrm{Si}$ in the residues compared to what was observed in the fresh ash samples (SFA and TFA) was as a result of the leaching of these species during the interaction tests. The trend observed for $\mathrm{Ca}$ and $\mathrm{Mg}$ showed that after the initial leaching of these species, they interacted with other species to form new mineral phases in the residues.

The acid consumption capacity of the ash residues

The $\mathrm{pH}$ profiles of the ash residues showed that when in contact with ultrapure water (no acid added), the $\mathrm{pH}$ of the ash residues was $>11$ in the case of SFA ash residues while the $\mathrm{pH}$ of TFA ash residues was between 10 and 11 (Fig. 1S1 and T1). The $\mathrm{pH}$ of the ash residues (SAC, SBC, SCC and SDC) and (TAC, TBC, TCC and TDC) decreased with an increase in the volume of acid in the leachants. Comparing the $\mathrm{pH}$ trends of the ash residues, it was observed that the $\mathrm{pH}$ profiles of the ash residues SAC and TAC (at 1 week) were slightly higher than the $\mathrm{pH}$ profiles of ash residues recovered at 1 month, 6 and 12 months

Table 1 Chemical composition of fresh fly ash (SFA) and ash residues (SAC, SBC, SCC and SDC) recovered at different long-term interaction periods $(n=2)$

\begin{tabular}{llllll}
\hline Element $(\mathrm{mg} / \mathrm{kg})$ & SFA & SAC & SBC & SCC & SDC \\
\hline $\mathrm{Al}$ & 137,751 & 133,993 & 133,041 & 133,517 & 132,353 \\
$\mathrm{Ca}$ & 66,467 & 66,110 & 65,824 & 65,895 & 65,824 \\
$\mathrm{Cl}$ & 73.9 & $1,798.2$ & $1,599.8$ & $1,644.7$ & $1,571.2$ \\
$\mathrm{~K}$ & 6,724 & 6,641 & 6,558 & 6,558 & 6,641 \\
$\mathrm{Mg}$ & 13,572 & 13,331 & 13,331 & 13,150 & 13,270 \\
$\mathrm{Na}$ & 4,525 & 6,083 & 6,009 & 6,603 & 7,270 \\
$\mathrm{~S}$ & $1,378.4$ & $4,616.3$ & $3,961.2$ & $3,271.1$ & $6,816.7$ \\
$\mathrm{Si}$ & 231,787 & 220,052 & 217,481 & 218,416 & 216,733 \\
$\mathrm{Sr}$ & $3,268.1$ & $3,553.7$ & $3,556.4$ & $3,549.3$ & $3,534.6$ \\
\hline
\end{tabular}


Table 2 Chemical composition of fresh fly ash (TFA) and ash residues (TAC, TBC, TCC and TDC) recovered at different long-term interaction periods $(n=2)$

\begin{tabular}{llllll}
\hline $\begin{array}{l}\text { Element } \\
(\mathrm{mg} / \mathrm{kg})\end{array}$ & TFA & TAC & TBC & TCC & TDC \\
\hline $\mathrm{Al}$ & 129,495 & 128,701 & 128,066 & 130,501 & 127,114 \\
$\mathrm{Ca}$ & 42,096 & 42,167 & 41,953 & 42,310 & 41,310 \\
$\mathrm{Cl}$ & 730.3 & 893.5 & $2,125.2$ & $3,370.1$ & $4,600.2$ \\
$\mathrm{~K}$ & 6,890 & 6,973 & 6,890 & 7,139 & 7,222 \\
$\mathrm{Mg}$ & 8,204 & 8,204 & 8,204 & 8,445 & 8,023 \\
$\mathrm{Na}$ & 2,151 & 3,709 & 4,154 & 4,303 & 4,896 \\
$\mathrm{~S}$ & $7,025.1$ & $4,928.5$ & $6,072.9$ & $6,437.7$ & $10,281.2$ \\
$\mathrm{Si}$ & 242,352 & 234,592 & 233,002 & 236,321 & 234,685 \\
$\mathrm{Sr}$ & $1,164.4$ & $1,312.1$ & $1,308.8$ & $1,302.9$ & $1,297.8$ \\
\hline
\end{tabular}

(SBC, SCC, SDC TBC, TCC and TDC). This implies that the ANC of the ash residues at 1 week is higher than that of the ash residues at 1 month, 6 and 12 months. Being a closed and static system, the 1-week period may not be enough for the rapid dissolution of the alkalinity-contributing oxides in the fly ashes during the long-term fly ashbrine interactions, thereby leaving significant amounts of some oxides such as $\mathrm{CaO}$ in the ash residues. Longer interaction periods (1-12 months) could cause the dissolution of more alkalinity-contributing oxides from the fly ashes and could also stabilize the new mineral phases formed in the ash residues. The dissolution of more $\mathrm{CaO}$ or $\mathrm{MgO}$ at longer interaction period could account for the slightly lower $\mathrm{pH}$ of the ash residues SBC, SCC, SDC, TBC, TCC and TDC. This indicates that the longer the ash is exposed to leaching and weathering, the lower the ANC of the ash.

The volume of acid required to achieve the final $\mathrm{pH} \approx 4$ in SAC, SBC, SCC and SDC was observed to be higher, and almost double the volume of acid required for TAC, TBC, TCC and TDC to achieve the same $\mathrm{pH}$ value. This implies that the neutralization capacity of SFA residues is higher than that of TFA residues. This phenomenon could be attributed to the higher percentages of $\mathrm{CaO}(9.3 \%)$ and $\mathrm{MgO}(2.3 \%)$ present in SFA compared to $\mathrm{CaO}(5.9 \%)$ and $\mathrm{MgO}(1.4 \%)$ in the TFA (Fatoba et al. 2011). The difference in the amounts of these oxides can be ascribed to the coal geology associated with the site from where the coal was mined. The oxides of $\mathrm{Ca}$ and $\mathrm{Mg}$ are the major alkalinity contributors in fly ash, and the concentrations of these basic oxides in the fly ash determine the $\mathrm{pH}$ of the fly ash when in contact with aqueous solution (Gitari et al. 2009). The lower buffering capacity of the TFA sample series indicates that the ash source would acidify more rapidly during weathering than the SFA series of samples.

The increase in the EC values as shown in Fig. 1S2 and T2 correlated directly with the increase in the volumes of acid added. This revealed the direct correlation of the $\mathrm{pH}$ of the leachants on the dissolution of components in the ash residues. The consistent increase in the $\mathrm{EC}$ with an increase in volumes of acid added suggested that apart from the dissolution of the easily soluble phases in the ash residues, phases insoluble at high $\mathrm{pH}$ were dissolved as the $\mathrm{pH}$ decreased, thereby increasing the concentrations of species in solution. Dijkstra et al. (2002) suggested that increased protonation at low $\mathrm{pH}$ causes a lower affinity of the species on the surfaces of the ash particles. The low affinity at low $\mathrm{pH}$ could result in an increase in the concentrations of species in solution which will directly lead to the increase in the EC of the systems. It is evident that the EC trends of the SFA residues were nearly double those of the TFA residues which indicate that the former was prone to leaching of more species into the environment than the latter. The difference in the EC of the SFA and TFA residues can be ascribed to the higher concentration of most of the species in the SFA (Tables 1 and 2).

The influence of $\mathrm{pH}$ on the release of major species

\section{Aluminum, silicon and strontium}

The results of the chemical composition of the excess brine decanted from the long-term fly ash-brine interaction systems, and the ash residues recovered from the interaction experiments showed that $\mathrm{Al}$ was leached out of the fly ashes into the brine solution even at the high $\mathrm{pH}$ of the systems (reported in Part I). The concentration of $\mathrm{Al}$ released from SFA and TFA ash residues (Fig. 2S3 and T3) into solution during the ANC tests was low at the initial $\mathrm{pH}$ $(\approx 12)$ after which the concentration of $\mathrm{Al}$ in the solution increased at $\mathrm{pH} 5-6$. The low concentration of $\mathrm{Al}$ observed at the initial $\mathrm{pH}$ of the ash residues up to a $\mathrm{pH}$ between 5 and 6 showed that low concentration of $\mathrm{Al}$ is available for leaching after the initial leaching during the long-term interactions experiments (reported in Part I). The increase observed at $\mathrm{pH}$ below 6 indicates that $\mathrm{Al}$ could be released from the ash residues under low $\mathrm{pH}$ conditions, which might not be envisaged in the real disposal scenario. The rapid and continuous increase in the concentration of $\mathrm{Al}$ at $\mathrm{pH}<6$ could be as a result of the dissolution of the aluminosilicate phases in the ash residues (Gitari et al. 2009). The slow initial release of $\mathrm{Al}$ in the ANC systems could be governed by the precipitation of amorphous phases at high 
Fig. $1 \mathrm{pH}$ and EC profiles of SFA ( $S 1$ and $S 2)$ and TFA ( $T 1$ and $T 2$ ) ash residues as a function of volume of acid added (acid consumption test)
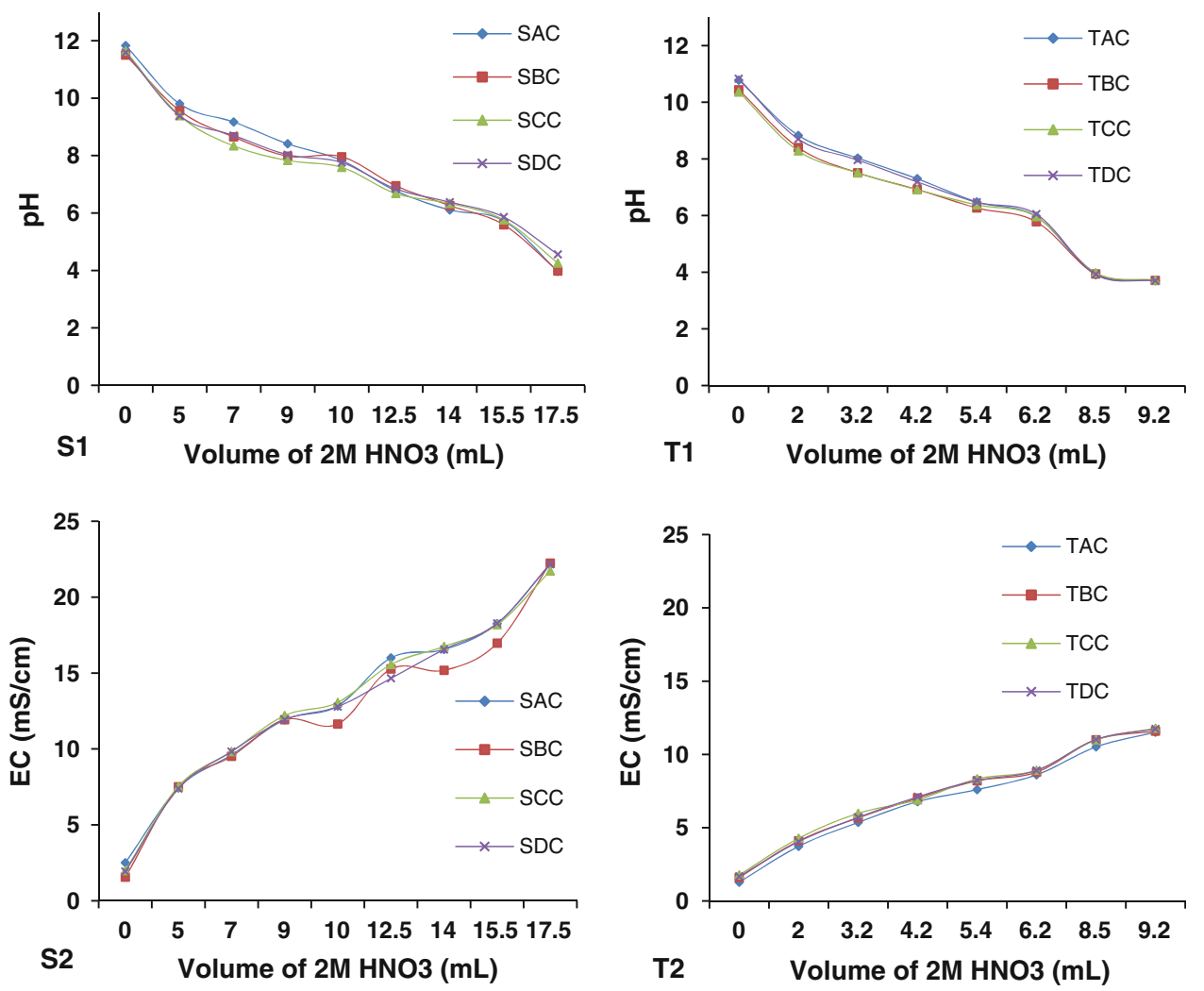

$\mathrm{pH}$ while the dissolution of the amorphous and crystalline mineral phases at lower $\mathrm{pH}$ could responsible for the increase thereafter. Studies (Kim et al. 2003; Ward et al. 2009; Izquierdo and Querol 2012; Dijkstra et al. 2006; Djedidi et al. 2009) have shown that at $\mathrm{pH}$ below the natural $\mathrm{pH}$ of fly ash (ranging between 6 and 8), the release of $\mathrm{Al}$ is controlled by the precipitation of $\mathrm{Al}$ (hydr)oxides such as $\mathrm{Al}(\mathrm{OH})_{3}$ from solution. The lower concentration of $\mathrm{Al}$ at $\mathrm{pH}$ between 6 and 10 could be attributed to the precipitation of amorphous Al-bearing phases in the systems. This indicates that the mobility of $\mathrm{Al}$ contained in the ash residues is low unless the $\mathrm{pH}$ should change significantly.

Similar to what was observed in the behavior of $\mathrm{Al}$ in the ash residues, the concentration of $\mathrm{Si}$ in the solutions of the ash residues was very low at higher $\mathrm{pH}(9-12)$ (Fig. 2S3 and T3), indicating that low concentration of Si is available for leaching in the ash residues after the initial leaching observed during the long-term interactions experiments (reported in Part I). After $\mathrm{pH}$ below 8, the concentration of $\mathrm{Si}$ in the solutions of ash residues increased significantly. Si is mainly contained in the silicate phases of fly ash. The increase observed at $\mathrm{pH}$ lower than 8 could be as a result of the dissolution of the silicate phases such as quartz $\left(\mathrm{SiO}_{2}\right)$ (Tiruta-Barna et al. 2006) in the ash residues. The effect of the longer interaction period was evident on the release of $\mathrm{Al}$ and $\mathrm{Si}$, as the ash residues recovered after 12 months (SDC and TDC) had the lowest concentrations of $\mathrm{Al}$ and $\mathrm{Si}$ released into the ANC leachates (Fig. 2S3 and S3). This implies that longer period of fly ash-brine interactions could reduce the dissolution of $\mathrm{Al}$ - and Si-bearing phases in the ash residues. However, the dissolution of the major aluminosilicate matrix has an effect on the release of other contaminants that are locked in the fly ash matrix.

The release of $\mathrm{Sr}$ from the ash residues into the ANC solutions at different $\mathrm{pH}$ was similar to those of $\mathrm{Ca}$ and $\mathrm{SO}_{4}$ (Fig. 2). Sr concentrations in the solutions of the ash residues in the ANC systems increased rapidly with a decrease in $\mathrm{pH}$ after the lowest concentration was observed in the leachates at the initial $\mathrm{pH}$ of the ash residues. The low concentration of $\mathrm{Sr}$ at the initial high $\mathrm{pH}$ could be as a result of secondary mineral formation during the interaction, as celestine $\left(\mathrm{SrSO}_{4}\right)$ was observed in the solid residues recovered after the fly ash-brine interactions [Part 1 (Fig. 4)]. The steady increase observed in the concentration of $\mathrm{Sr}$ at $\mathrm{pH}$ between 9 and 12 (possible $\mathrm{pH}$ in real disposal scenario) indicates that $\mathrm{Sr}$ could continuously leach from 
Fig. $2 \mathrm{Si}, \mathrm{Al}, \mathrm{Sr}, \mathrm{B}, \mathrm{Ca}$ and $\mathrm{SO}_{4}$ concentrations released from SFA (S3-S5) and TFA (T3-T5) ash residues at different $\mathrm{pH}$ (ANC leaching test)
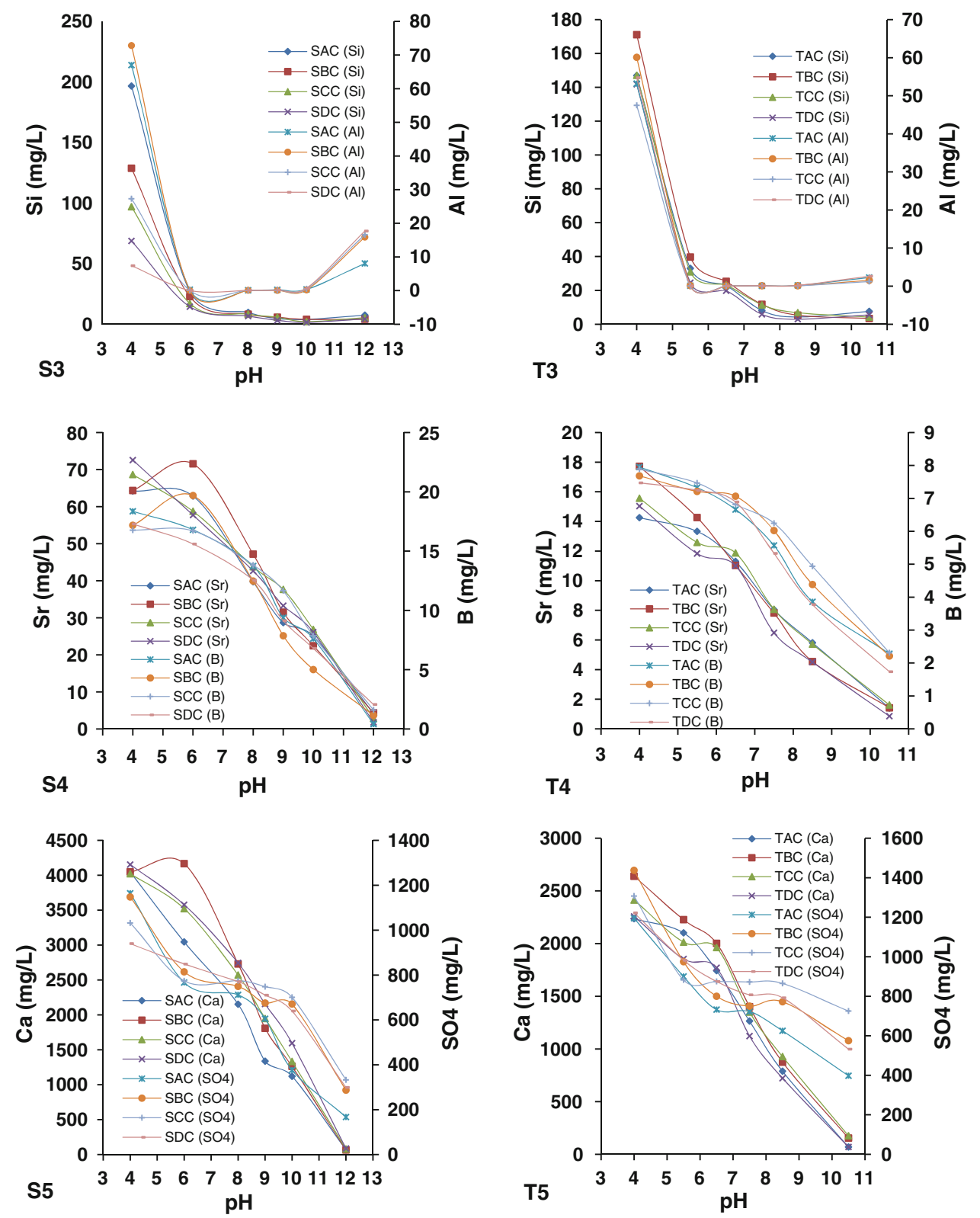

the residues despite the leaching observed during the longterm interactions experiments (reported in Part I). The trend of the release of $\mathrm{Sr}$ indicates its dependence on the $\mathrm{pH}$ of the leachants added. The increase in the release of $\mathrm{Sr}$ at low $\mathrm{pH}$ could indicate that the low $\mathrm{pH}$ did not favor the formation of Sr-rich mineral phases but rather enhanced dissolution of Sr-containing phases.

\section{Boron, calcium and sulfate}

The results of the excess brine decanted from the longterm interactions experiments reported in Part I of this study showed that $B$ was removed from the brine solution. The concentration of B in the ANC leachates of SFA ash residues was very low at the initial high $\mathrm{pH}$ $(\approx 12)$ while the B concentration in the ANC leachates of TFA ash residues was a bit higher (Fig. 2S4 and T4). This shows the effect of final $\mathrm{pH}$ of the systems on the release of $\mathrm{B}$ from the ash residues. At high $\mathrm{pH}, \mathrm{B}$ exists in aqueous solution as oxy-anion (Iwashita et al. 2005; Jankowski et al. 2006) such as borate. Studies (Zhang and Reardon 2003; Iwashita et al. 2005; Hassett et al. 2005; Izquierdo and Querol 2012) have shown that the formation of ettringite $\left[\mathrm{Ca}_{6} \mathrm{Al}_{2}\left(\mathrm{SO}_{4}\right)_{3} \cdot 26 \mathrm{H}_{2} \mathrm{O}\right]$ phase in highly alkaline solution could reduce $\mathrm{B}$ concentration. $\mathrm{B}$ which exists as oxy-anion could be trapped in the ettringite by 
replacing its sulfate component with the oxy-anion form of B. Co-precipitation of $\mathrm{B}$ with $\mathrm{CaCO}_{3}$ was also suggested to contribute to the low concentration of $\mathrm{B}$ in alkaline solution (Jankowski et al. 2006). The initial low concentration of $\mathrm{B}$ in the leachate solution of SFA residues at the start of the ANC tests could indicate nondissolution of the B-containing/entrapping phases when in contact with ultrapure water at high $\mathrm{pH}$. The increase observed in the concentration of $\mathrm{B}$ as the $\mathrm{pH}$ decreased could be attributed to the dissolution of the B-containing phases. The continuous leaching observed in the case of $\mathrm{B}$ in TFA ash residues as the $\mathrm{pH}$ decreased could be attributed to the dissolution of $\mathrm{B}$ from the matrix of the ash residues. Although the concentration of $\mathrm{B}$ released from each of the ash residues during the ANC tests was almost the same at each specific $\mathrm{pH}$, the release of $\mathrm{B}$ from the ash residues generated at 12 months (SDC and TDC) was lower when compared to other ash residues. This observation revealed the effect of the long-term interaction periods on the mobility of $\mathrm{B}$ in the ash residues when in contact with solutions of different $\mathrm{pH}$ values.

The XRF results showing the chemical composition of the ash residues recovered after the long-term fly ash-brine interaction experiments showed very little difference compared to the concentration of $\mathrm{Ca}$ before the long-term experiments (Tables 1 and 2). This may indicate that the $\mathrm{Ca}$ that leached from the fly ash has interacted with other species to form new mineral phases in the ash residues. The concentration of $\mathrm{Ca}$ in the leachates from the ANC tests of both SFA and TFA ash residues (SAC, SBC, SCC and SDC, and TAC, TBC, TCC and TDC) was low at the initial high $\mathrm{pH}$ of the ash residues (Fig. 2S5 and T5). However, a steady and significant increase in $\mathrm{Ca}$ concentration in leachates was observed with a decrease in the $\mathrm{pH}$ of the ANC systems. The low concentration of $\mathrm{Ca}$ at the initial high $\mathrm{pH}$ of the ANC systems could be as a result of the significant concentration of $\mathrm{Ca}$ that was leached into the brine solution (reported in Part I) during the long-term interaction experiments, which could have reduced the concentration of easily soluble $\mathrm{Ca}$ in the ash residues. The low concentrations of $\mathrm{Ca}$ at the initial high $\mathrm{pH}$ of the ANC systems could also indicate that the probable Ca-bearing mineral phase(s) that may have formed in the residues during the long-term interaction experiments was stable at high $\mathrm{pH}$. Apart from these, the high natural $\mathrm{pH}(>11)$ of the ANC systems at the beginning of the tests could favor the precipitation of Ca-rich phases, thereby reducing the concentration of $\mathrm{Ca}$ released into the solution at natural $\mathrm{pH}$. However, a rapid and continuous increase in the concentrations of $\mathrm{Ca}$ observed as the $\mathrm{pH}$ decreased could be attributed to the dissolution of any secondary Ca-rich mineral phases in the ash residues. The dissolution of gypsum has been observed to govern the solubility of $\mathrm{Ca}$ between pH 4 and 8 (Dijkstra et al. 2006). Vitkova et al. (2013) observed non-stoichiometric release of $\mathrm{Ca}$ at high $\mathrm{pH}$ ranges after which a congruent dissolution of calcium silicate followed at lower $\mathrm{pH}$. At low $\mathrm{pH}$, there could be competitive replacement of $\mathrm{Ca}$ ions with the $\mathrm{H}^{+}$in solution, thereby leading to the release of more $\mathrm{Ca}$ ions. The dissolution of mineral phases such as $\mathrm{CaCO}_{3}$, gypsum or ettringite which may have precipitated out during the longterm fly ash-brine interactions experiments could be attributed to the significant increase in Ca concentrations in the ANC leachates at low pH (Iwashita et al. 2005).

The concentration of $\mathrm{SO}_{4}$ released into the leachates of the ANC tests from SFA and TFA ash residues was initially high at initial high $\mathrm{pH}$ of the ANC systems (Fig. 2S5 and T5). The concentration of $\mathrm{SO}_{4}$ thereafter increased significantly with a decrease in the $\mathrm{pH}$ of the ANC systems. The results presented in Tables 1 and 2 showed that $\mathrm{SO}_{4}$ was significantly removed from the brine solution by the fly ashes during the long-term fly ash-brine interaction experiments. However, the immediate increase observed in the concentration of $\mathrm{SO}_{4}$ when the ash residues contacted water (natural $\mathrm{pH}$ ) at the start of the ANC tests indicated the rapid release of soluble $\mathrm{SO}_{4}$ species that had been removed from the brine during interaction with the fly ashes. The continuous increasing trend of release can be attributed to the rapid dissolution of any $\mathrm{SO}_{4}$-rich secondary mineral phases formed in the ash residues as the $\mathrm{pH}$ decreased, showing the instability and high solubility of the mineral phases that captured sulfate. The trends of release of $\mathrm{SO}_{4}$ from the ash residues indicate that these species that were removed from the brine solution by contact with the fly ashes are labile and thus mobile even at high $\mathrm{pH}$ upon contact with water. The ANC tests demonstrated that the removal of $\mathrm{SO}_{4}$, as observed in the long-term fly ash-brine interaction experiments, would not be maintained in the real scenario and dissolution would rapidly occur upon water ingress or any $\mathrm{pH}$ changes. The rapid release of $\mathrm{SO}_{4}$ from the ash residues has significant impacts on the environment and would account for the increasing $\mathrm{SO}_{4}$ levels in the water bodies in the catchment area where the ash dumps are located.

\section{Magnesium, potassium, sodium and chloride}

The results of the chemical composition of the excess brine decanted from the ash residues after the long-term fly ashbrine interaction experiments showed that $\mathrm{Mg}$ was removed 
by the fly ashes at high $\mathrm{pH}$ of the long-term fly ash-brine interaction tests (reported in Part I) under static conditions over a period of 12 months. However, the concentration of $\mathrm{Mg}$ in the ANC leachates of SFA and TFA ash residues was very low at the initial high $\mathrm{pH}$ of the ANC tests, whereafter a rapid increase in $\mathrm{Mg}$ concentration was observed with a decrease in $\mathrm{pH}$ (Fig. 3S6 and T6). The low concentration of $\mathrm{Mg}$ at the initial high $\mathrm{pH}$ of the ash residues when in contact with ultrapure water at the start of the ANC tests could indicate that the probable $\mathrm{Mg}$-rich mineral phases that precipitated during the long-term interactions experiments are not mobile at high $\mathrm{pH}$ (when in contact with ultrapure water). At high $\mathrm{pH}$, the solubility of $\mathrm{Mg}$ is controlled by the formation of either $\mathrm{Mg}(\mathrm{OH})_{2}$ (Gitari et al. 2009; Dijkstra et al. 2006; Vitkova et al. 2013) or by the more stable $\mathrm{Mg}$ layered double hydroxide (LDH) phase $\left(\mathrm{Mg}_{2} \mathrm{Al}(\mathrm{OH})_{6}\right.$ $\left(-\mathrm{CO}_{3}\right)_{0.5} \cdot \mathrm{H}_{2} \mathrm{O}$ (Johnson and Glasser 2003). $\mathrm{Mg}$ was found to be a less readily soluble component of fly ash due to its incorporation mostly in the glass phases of the fly ash (Ugurlu 2004). The continuous increase and high release of $\mathrm{Mg}$ in ANC leachates as the $\mathrm{pH}$ decreased upon acidification shows the possible dissolution of Mg-rich phases incorporated in the brine impacted fly ash upon weathering of the ash.

The release of $\mathrm{K}$ was found to be slightly different to that of $\mathrm{Mg}$ as significant quantity of $\mathrm{K}$ was released at high
pH after which a gradual increase was observed with decrease in the $\mathrm{pH}$ values upon acidification (Fig. 3S6 and T6). The chemical composition of the brine decanted after the long-term interactions experiments showed that $\mathrm{K}$ was leached from the fly ashes into the brine solution (reported in Part I). The increase observed in the concentration of $\mathrm{K}$ at the initial high $\mathrm{pH}$ of the ash residues and during $\mathrm{pH}$ changes applied in the ANC tests is an indication that more $\mathrm{K}$ would leach from the fly ashes despite the initial leaching observed during the long-term interaction experiments. This suggests that, apart from the soluble salts of $\mathrm{K}$ in the fly ashes, $\mathrm{K}$ could also be present in the matrix of the ash residues. The slow release of K observed in SFA and TFA ash residues as the $\mathrm{pH}$ decreased could be attributed to the dissolution of less soluble phases in the ash residues.

The chemical composition of the excess brine decanted and the ash residues recovered after the long-term fly ashbrine interaction experiments showed that $\mathrm{Na}$ was removed, to some extent, from the brine solution by the fly ashes under long-term static conditions at high $\mathrm{pH}$ (reported in Part I). The release of $\mathrm{Na}$ into the ANC leachates exhibits rapid and high leaching behavior that was independent of $\mathrm{pH}$ (Fig. 3S7 and T7). The concentration of $\mathrm{Na}$ in the leachates was immediately high at the initial high $\mathrm{pH}$ of the ANC systems showing the high solubility of $\mathrm{Na}$ in ash residues, and this high concentration
Fig. $3 \mathrm{Mg}, \mathrm{K}, \mathrm{Na}$ and $\mathrm{Cl}$ concentrations released from SFA (S6-S7) and TFA (T6-T7) ash residues at different $\mathrm{pH}$ (ANC leaching test)
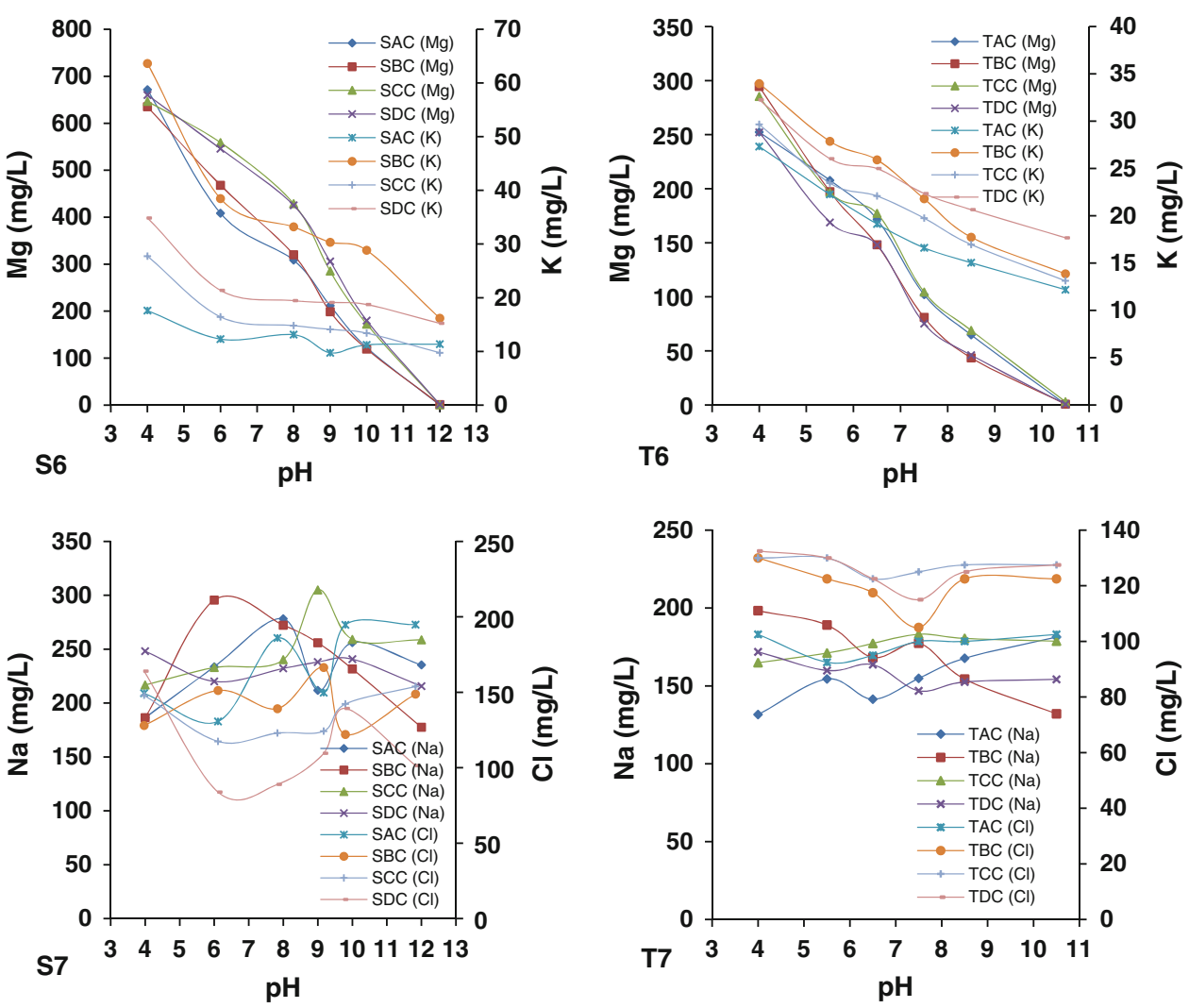
was maintained irrespective of the $\mathrm{pH}$ of the systems. The trends of release of $\mathrm{Na}$ in the ANC systems suggest the rapid dissolution of any transient Na-rich soluble salts such as halite $(\mathrm{NaCl})$ or $\mathrm{Na}_{2} \mathrm{SO}_{4}$ (Wang et al. 2010; Quina et al. 2009; Tiruta-Barna et al. 2004) that may have formed in the ash residues during the long-term fly ash-brine interaction experiments. The release of significant amounts of $\mathrm{Na}$ at the initial high $\mathrm{pH}$ of the ANC systems is an indication that the Na removed from the brine solution by the fly ashes during the long-term fly ash-brine interaction experiments is highly mobile immediately on contact with water.

The release of $\mathrm{Cl}$ from SFA and TFA ash residues into the ANC solution followed the same $\mathrm{pH}$-independent trend as that of $\mathrm{Na}$. The similarity in the release of $\mathrm{Na}$ and $\mathrm{Cl}$ into ANC leachates suggests the possible interaction of these species to form transient mineral phases such as $\mathrm{NaCl}$ during the long-term interaction experiments. The concentration of $\mathrm{Cl}$ released from both ash residues was high in the leachates of the ANC tests at the initial high $\mathrm{pH}$ of the ash residues (Fig. 3S7 and T7). The trend of the release continued and was fluctuating throughout the ANC tests irrespective of the $\mathrm{pH}$ of the leaching solution. The results showing the chemical composition of the brine decanted from the long-term fly ash-brine interaction experiments (reported in Part I) and the XRF results of the ash residues after the long-term interactions experiments (Tables 1 and 2) showed that the fly ashes initially removed significant amounts of the $\mathrm{Cl}$ in the brine solution under the static conditions applied. However, the high concentration of $\mathrm{Cl}$ in the ANC tests irrespective of the $\mathrm{pH}$ showed that the $\mathrm{Cl}$ removed by the fly ashes during the long-term interactions experiments was highly mobile. This is a clear indication that any form of secondary mineral phase(s) in which $\mathrm{Cl}$ may exist in the ash residues is transient and very soluble.

Percentage of species released from the ash residues at different $\mathrm{pH}$

The percentages $(\%)$ of selected species released from the ash residues at different $\mathrm{pH}$ during the ANC tests are shown in Figs. 4 and 5. This is to determine the percentage of the major species in the ash residues that are mobile under different $\mathrm{pH}$ conditions. Some species that leached from the fly ashes into the brine solution during the longterm fly ash-brine interaction experiments were also considered in this calculation in order to determine whether the species were continuously released from the ash residues.

The extraction percentage $\left(E_{\mathrm{p}}\right)$ was calculated using the total chemical composition of the ash residues and the concentration of species released into the ANC leachates from the ash residues. The extraction percentage value was
Fig. 4 Percentage (\%) of elements leached from ash residues $(S A C, S B C, S C C$ and $S D C)$ at different $\mathrm{pH}$
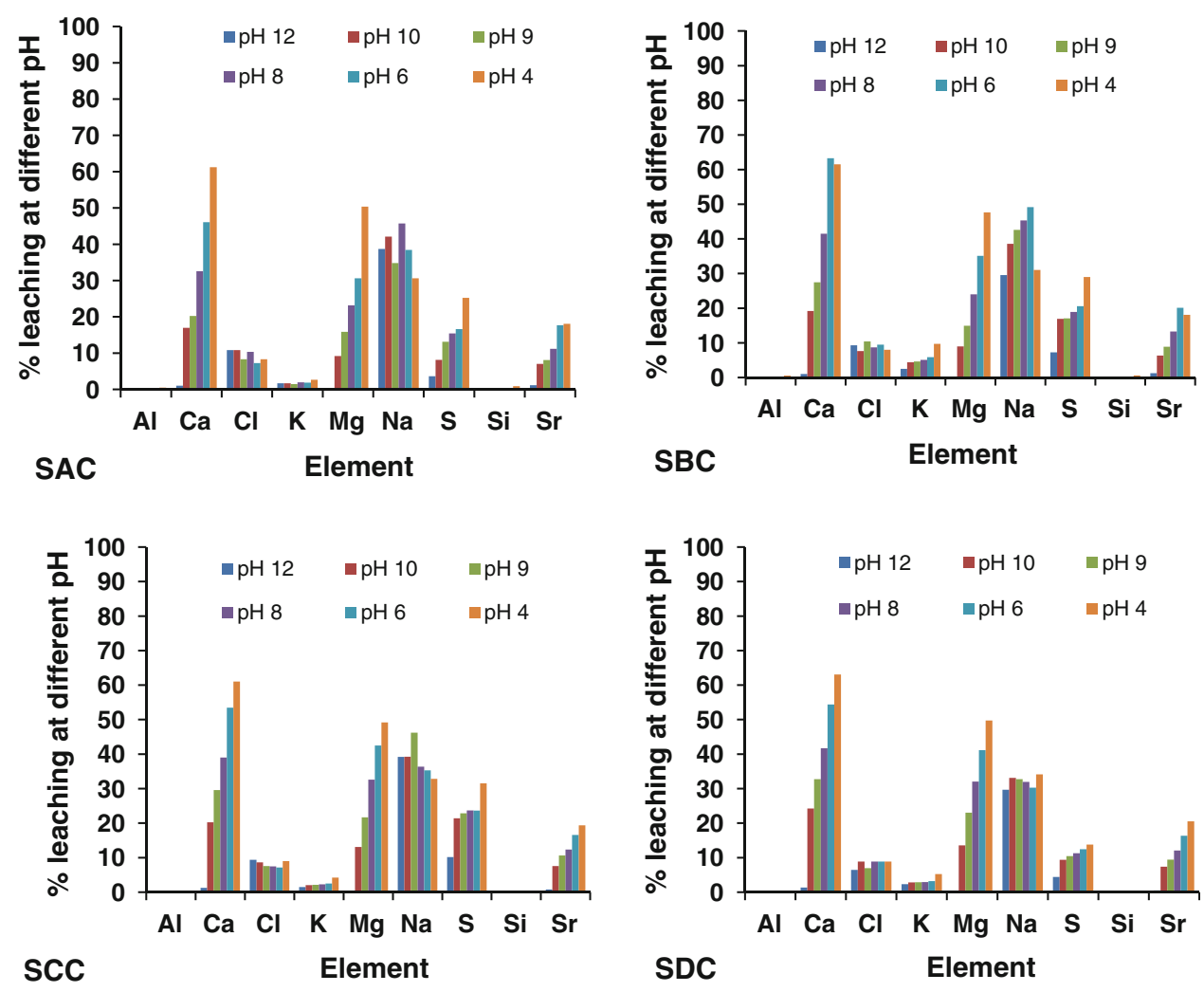
Fig. 5 Percentage $(\%)$ of elements leached from ash residues $(T A C, T B C, T C C$ and $T D C$ ) at different $\mathrm{pH}$
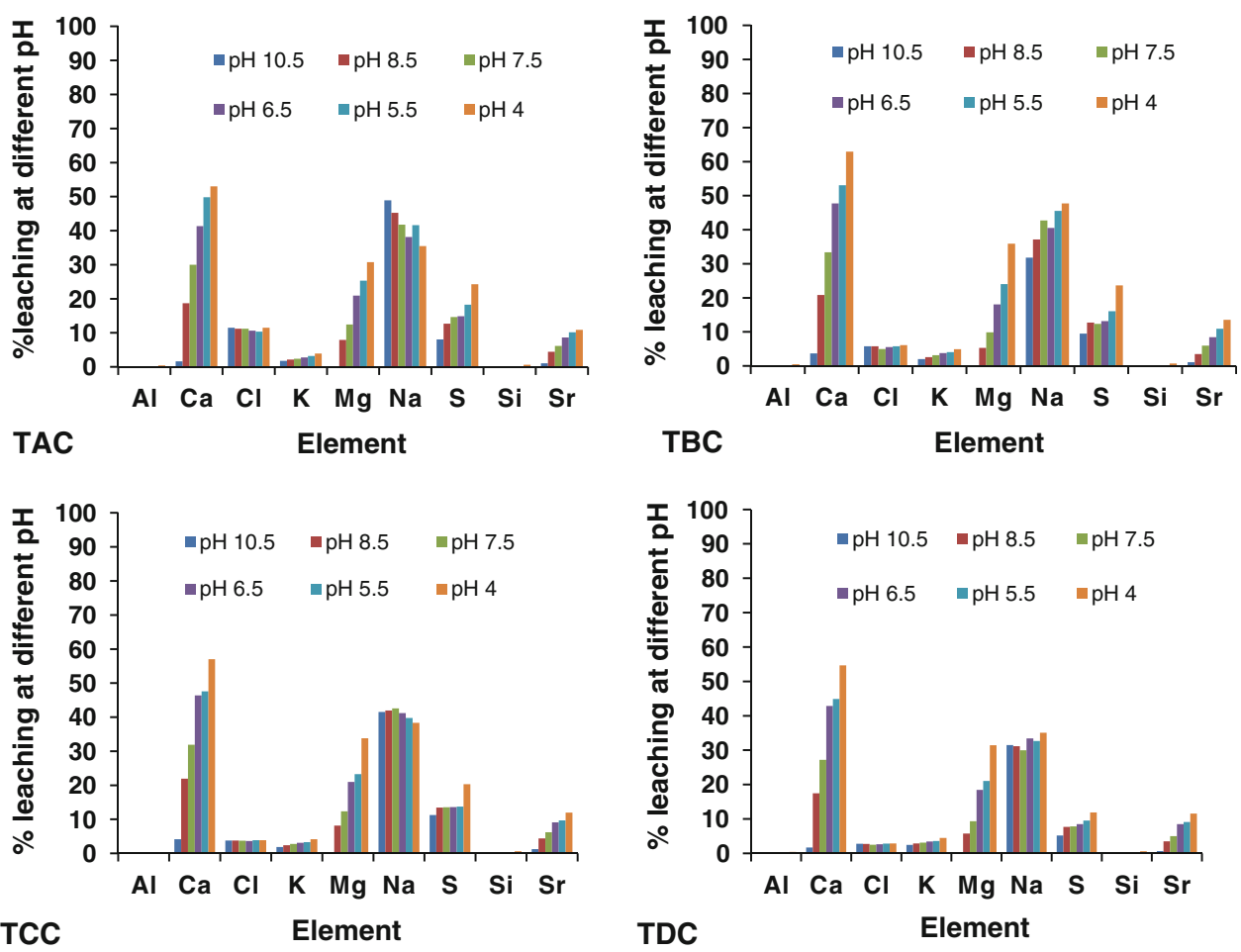

calculated according to the formula adapted from Baba et al. (2008).

$E_{\mathrm{p}}=\left(C_{\mathrm{l}} / C_{\mathrm{s}}\right) \times 100$

where $E_{\mathrm{p}}$ is the extraction percentage of each species (\%), $C_{1}$ is the concentration of the species in the leachate $(\mathrm{mg} /$ $\mathrm{L})$, and $C_{\mathrm{s}}$ the concentration of the species in ash residue (mg/L).

The extraction percentage of most of the species released from the ash residues at the initial high $\mathrm{pH}(\mathrm{pH} 12$ for SFA ash residues and $\mathrm{pH} 10.5$ for TFA ash residues) was very low except for $\mathrm{Na}, \mathrm{Cl}, \mathrm{K}$ and $\mathrm{S}\left(\mathrm{SO}_{4}\right)$. The extraction percentage of $\mathrm{Na}$ and $\mathrm{Cl}$ in the $\mathrm{ANC}$ leachates was observed to be high with values ranging from 29.7 to $39.2 \%$ in the SFA ash residues and from 31.5 to $48.9 \%$ in TFA ash residue leachates. The low solubility of most of these species at the initial high $\mathrm{pH}(>10)$ could be as a result of precipitation and adsorption processes (Zhang et al. 2008; Bozkurt et al. 2000). Low retention observed for $\mathrm{Na}$ and $\mathrm{Cl}$ in the ash residues at high $\mathrm{pH}$ indicates their presence as easily soluble salts in the ash residues. As the $\mathrm{pH}$ decreased, the extraction percentage of some species such as $\mathrm{Ca}, \mathrm{Mg}, \mathrm{S}\left(\mathrm{SO}_{4}\right)$ and $\mathrm{Sr}$ increased significantly especially at $\mathrm{pH}$ 4. The increase in the concentrations of these species could be attributed to the dissolution of mineral phases containing the species and the inability of these species in the ANC leachates to form secondary mineral phases due to the low $\mathrm{pH}$. Generally, the extraction percentages of the species released from the ash residues showed that the mobility of $\mathrm{Mg}, \mathrm{Al}$ and $\mathrm{Si}$ is low and that these species would only be released from the ash residues at extreme conditions such as very low $\mathrm{pH}$. On the other hand, the results (Figs. 4 and 5) showed that a significant amount of $\mathrm{Na}, \mathrm{Cl}$ and $\mathrm{S}\left(\mathrm{SO}_{4}\right)$ removed from the brine solution during the long-term interaction experiments (reported in Part I) is immediately mobile when in contact with water.

\section{Conclusion}

This study shows that the $\mathrm{Na}$ and $\mathrm{Cl}$ captured in the ash residues are highly soluble and could easily leach out of the ash residues when in contact with aqueous solution irrespective of the $\mathrm{pH}$. The ANC study shows that the $\mathrm{SO}_{4}$ removed from the brine solution by the fly ashes during the interaction experiment is not in stable forms and are mobile when in contact with water, as significant concentration of $\mathrm{SO}_{4}$ was released at high $\mathrm{pH}$ possible in the real fly ash disposal systems. The amount of species that can be 
leached out of fly ash at different $\mathrm{pH}$ depends on the concentration of each of the species in the fly ash, which in-turn is a function of the source of coal burnt. However, comparing the concentrations of $\mathrm{Na}$ and $\mathrm{Cl}$ released from the ash residues with the concentrations released from fresh fly ash or MSWI ash investigated in other studies, the concentrations of $\mathrm{Na}$ and $\mathrm{Cl}$ released from the brine impacted ash residues were much higher. This is an indication that $\mathrm{Na}$ and $\mathrm{Cl}$ captured in the ash residues during the fly ash-brine interaction tests were later released into solution when in contact with the leachants. Despite the significant leaching of $\mathrm{Al}$ and $\mathrm{Si}$ during the long-term fly ash-brine interaction tests as reported in Part I, the slow continuous leaching of $\mathrm{Al}$ and $\mathrm{Si}$ from the brine impacted residues at $\mathrm{pH}$ 6-12 shed more light into the long-term leaching behavior of $\mathrm{Al}$. The continuous leaching of the major species such as $\mathrm{Na}, \mathrm{Cl}, \mathrm{SO}_{4}, \mathrm{Al}$ and $\mathrm{Si}$ from the ash residues at $\mathrm{pH}$ 6-12, which is possible in the real disposal scenario, gives an insight into the long-term effect of the fly ash-brine co-disposal techniques. The application of the ANC tests to determine the stability of the secondary mineral phases that may have formed in the brine impacted ash residues, and the mobility of the species when in contact with solutions of different $\mathrm{pH}$ values revealed that fly ash may not be used to sustainably capture the salt in brine solution in the real co-disposal systems.

Acknowledgments The authors would like to appreciate Eskom and Sasol in South Africa for funding this research project.

\section{References}

Astrup T, Mosbaek H, Christensen TH (2006) Assessment of longterm leaching from waste incineration air-pollution-control residues. Waste Manag 26(8):803-814

Baba A, Gurdal G, Sengunalp F, Ozay O (2008) Effects of leachant temperature and $\mathrm{pH}$ on leachability of metals from fly ash. A case study: can thermal power plant, province of Canakkale, Turkey. Environ Monit Assess 139:287-298

Bozkurt S, Moreno L, Neretnieks I (2000) Long-term processes in waste deposits. Sci Total Environ 250:101-121

CEN (2003) prEN 14429: characterization of waste-leaching behaviour tests-influence of $\mathrm{pH}$ on leaching with initial acid/ base addition. CEN TC292/WG6, NNI, Delft, The Netherlands

Dijkstra JJ, Van der Sloot HA, Comans RNJ (2002) Process identification and model development of contaminant transport in MSWI bottom ash. Waste Manag 22:531-541

Dijkstra JJ, Van der Sloot HA, Comans RNJ (2006) The leaching of major and trace elements from MSWI bottom ash as a function of $\mathrm{pH}$ and time. Appl Geochem 21:335-351

Djedidi Z, Bouda M, Souissi MA, Cheikh RB, Mercier G, Tyagi RD, Blais J (2009) Metals removal from soil, fly ash and sewage sludge leachates by precipitation and dewatering properties of the generated sludge. J Hazard Mater 172:1372-1382
ESKOM Report (2013) Ash management in ESKOM, fact sheet number CO 0004. http://www.eskom.co.za. Accessed 22 March 2013

Fatoba OO, Petrik LF, Gitari WM, Iwuoha EI (2011) Fly ash-brine interaction: removal of major and trace elements from brine. J Environ Sci Health Part A 46:1648-1666

Gitari WM, Fatoba OO, Petrik LF, Vadapalli VRK (2009) Leaching characteristics of selected South African fly ashes: effect of $\mathrm{pH}$ on the release of major and trace species. J Environ Sci Health Part A 44(2):206-220

Hassett DJ, Pflughoeft-Hassett DF, Heebink LV (2005) Leaching of CCBs: observations from over 25 years of research. Fuel 84: 1378-1383

Iwashita A, Sakaguchi Y, Nakajima T, Takanashi H, Ohki A, Kambara S (2005) Leaching characteristics of boron and selenium for various coal fly ashes. Fuel 84:479-485

Izquierdo M, Querol X (2012) Leaching behaviour of elements from coal combustion fly ash: an overview. Int $\mathrm{J}$ Coal Geol 94:54-66

Jankowski J, Ward CR, French D, Groves S (2006) Mobility of trace elements from selected Australian fly ashes and its potential impact on aquatic ecosystems. Fuel 85:243-256

Johnson CA, Glasser FP (2003) Hydrotalcite-like minerals $\mathrm{M}_{2} \mathrm{Al}(\mathrm{OH})_{6}\left(\mathrm{CO}_{3}\right)_{0.5} \cdot \mathrm{XH}_{2} \mathrm{O}$, where $\mathrm{M}=\mathrm{Mg}, \mathrm{Zn}, \mathrm{Co}$., $\mathrm{Ni}$ in the environment: synthesis, characterization and thermodynamic stability. Clays Clay Miner 51:1-8

Kim AG, Kazonich G, Dahlberg M (2003) Relative solubility of cations in class F fly ash. Environ Sci Technol 37:4507-4511

Quina MJ, Bordado JCM, Quinta-Ferreira RM (2009) The influence of $\mathrm{pH}$ on the leaching behaviour of inorganic components from municipal solid waste APC residues. Waste Manag (Oxf) 29: 2483-2493

Sushil S, Batra SV (2006) Analysis of fly ash heavy metal content and disposal in three thermal power plants in India. Fuel 85: 2676-2679

Tiruta-Barna L, Imyim A, Barna R (2004) Long-term prediction of the leaching behaviour of pollutants from solidified wastes. Adv Environ Res 8:697-711

Tiruta-Barna L, Rakotoarisoa Z, Mehu J (2006) Assessment of the multi-scale leaching behaviour of compacted coal ash. J Hazard Mater B137:1466-1478

Ugurlu A (2004) Leaching characteristics of fly ash. Environ Geol 46(6-7):890-895

Van der Sloot HA, Dijkstra JJ (2004) Development of horizontally standardized leaching tests for construction materials: a material based or released based approach? ECN-C-04-060. Energy Research Centre of the Netherlands (ECN), Petten, The Netherlands

Van Herreweghe S, Swennen R, Cappuyns V, Vandecasteele C (2002) Chemical associations of heavy metals and metalloids in contaminated soils near former ore treatment plants: a differentiated approach with emphasis on $\mathrm{pH}$ stat-leaching. J Geochem Explor 76:113-138

Vitkova M, Ettler V, Sebek O, Mihaljevic M, Grygar T, Rohovec J (2009) The pH-dependent leaching of inorganic contaminants from secondary lead smelter fly ash. J Hazard Mater 167: $427-433$

Vitkova M, Hyks J, Ettler V, Astrup T (2013) Stability and leaching of cobalt smelter fly ash. Appl Geochem 29:117-125

Wang W, Zheng L, Wang F, Wan X, Yin K, Gao X (2010) Release of elements from municipal solid waste incineration fly ash. Front Environ Sci Engin China 4(4):482-489 
Ward CR, French D, Jankowski J, Dubikova M, Li Z, Riley KW (2009) Element mobility from fresh and long-stored acidic fly ashes associated with an Australian power station. Int J Coal Geol 80:224-236

Zhang M, Reardon EJ (2003) Removal of B, Cr, Mo, and Se from wastewater by incorporation into hydrocalumite and ettringite. Environ Sci Technol 37(13):2947-2952
Zhang Y, Jiang J, Chen M (2008) MINTEQ modeling for evaluating the leaching behavior of heavy metals in MSWI fly ash. J Environ Sci 20:1398-1402 